\title{
Physico-chemical characterization and biological studies of newly synthesized metal complexes of an Ionic liquid-supported Schiff base: 1-\{2-[(2-hydroxy-5-bromobenzylidene)amino]ethyl\}-3- ethylimidazolium tetrafluoroborate
}

\author{
SANJOY SAHA ${ }^{\mathrm{a}, *}$, GOUTAM BASAK ${ }^{\mathrm{b}}$ and BISWAJIT SINHA ${ }^{\mathrm{c}}$ \\ ${ }^{a}$ Department of Chemistry, Kalimpong College, Kalimpong, West Bengal 734 301, India \\ ${ }^{b}$ Department of Microbiology, Raiganj University, Raiganj, West Bengal 733 134, India \\ ${ }^{c}$ Department of Chemistry, University of North Bengal, Darjeeling, West Bengal 734 013, India \\ E-mail: sanjoychem83@yahoo.com
}

MS received 31 August 2017; revised 22 November 2017; accepted 22 November 2017; published online 1 February 2018

\begin{abstract}
Co}(\mathrm{II}), \mathrm{Ni}(\mathrm{II})$ and $\mathrm{Cu}(\mathrm{II})$ complexes of an ionic liquid-supported Schiff base 1-\{2-[(2-hydroxy-5bromobenzylidene)amino]ethyl $\}$-3-ethylimidazolium tetrafluoroborate were synthesized and characterized by various analytical and spectroscopic methods such as elemental analysis, UV-Visible, FT-IR, ${ }^{1} \mathrm{H}$ NMR, ESI MS, molar conductance and magnetic susceptibility measurements. Based on the spectral studies, tetra coordinated geometry was proposed for the complexes and molar conductance of the complexes revealed their electrolytic nature. The synthesized Schiff base and its complexes were evaluated for in vitro antibacterial activities against Gram positive and Gram negative bacteria. The complexes along with the Schiff base showed very significant biological activity against the tested bacteria.
\end{abstract}

Keywords. Ionic liquid-supported Schiff base; Co (II)complex; Ni (II)complex; Cu (II)complex; antibacterial activity.

\section{Introduction}

Ionic liquids (ILs) are organic salts which have low melting points below the boiling point of water and are stable in a liquid state at $100^{\circ} \mathrm{C}$, even at room temperature. They can exhibit numerous desirable properties such as negligible vapor pressure, ${ }^{1}$ ability to dissolve various substrates, high electrical conductivity ${ }^{2}$ and thermal stability. ${ }^{3-5}$ ILs are touted as alternatives to volatile organic solvents (VOC) in various organic transformations. Due to low toxicity and biodegradability, they have been termed as green solvents. ${ }^{6}$ An unusual feature of ILs is the tenability of their physical and chemical properties by variation of cations and anions. Usually, large organic cations and smaller anions are designed to carry on required functions. ${ }^{7}$ Although most of the works on ILs highlight their use as reaction media in organic synthesis, these liquids are gradually drawing attention in

\footnotetext{
*For correspondence
}

the field of inorganic and material chemistry. ${ }^{8,9}$ The concept of functionalized ionic liquid (FILs), by introducing additional a functional group as a part of cation or anion, has presently become a subject of interest. ${ }^{10-15}$ There is a huge possibility of chemical structure modifications through the incorporation of specific functionality. Such FILs are able to interact with a metal centre and contribute to enhanced stability of metal salts. ${ }^{16}$ Metal-containing ILs are considered as promising new materials that combine the feature of ILs with additional intrinsic magnetic, catalytic and spectroscopic properties depending on the incorporated metal ion. ${ }^{17}$

Schiff bases, usually formed by the condensation of a primary amine with an aldehyde are one of the most prevalent ligands in coordination chemistry. ${ }^{18}$ Schiff bases containing hetero-atoms such as nitrogen, oxygen and sulphur are of special interest due to their different ways of bonding with transition metal ions and unusual configuration. ${ }^{19}$ They have been reported to exhibit a variety of biological actions due to the presence of azomethine linkage, which is responsible for different 
types of antibacterial, herbicidal and antifungal activities. ${ }^{20,21}$ Transition metal complexes of Schiff bases carrying nitrogen and other donor sites have a variety of applications including biological, medicinal analytical in addition to their vital role in organic synthesis and catalysis. ${ }^{22-26}$ We reported in previous articles the synthesis, characterization and biological influence of $\mathrm{Cu}(\mathrm{II}), \mathrm{Mn}(\mathrm{II})$ and $\mathrm{Co}(\mathrm{II})$ complexes of analogous ionic liquid-supported Schiff bases. ${ }^{27,28}$ This paper reports on the synthesis of transition metal $\mathrm{Co}(\mathrm{II}), \mathrm{Ni}(\mathrm{II})$ and $\mathrm{Cu}(\mathrm{II})$ complexes of an ionic liquid-supported Schiff base and their characterization using spectroscopic, analytical and magnetic data. Furthermore, the applications of the Schiff base and its complexes as potential antibacterial agents have also been demonstrated.

\section{Experimental}

\subsection{Materials}

All the reagents used were of analytical grade and used without further purification. 1-ethylimidazole, 2-bromoethylamine hydrobromide and sodium tetrafluoroborate were procured from Sigma Aldrich, Germany. 5-bromo-2-hydroxy benzaldehyde, $\mathrm{Co}(\mathrm{II}), \mathrm{Ni}$ (II) and $\mathrm{Cu}(\mathrm{II})$ acetates and all other chemicals were used as received from SD Fine Chemicals, India. The solvents methanol, petroleum ether, chloroform, DMF and DMSO were used after purification by the standard methods described in the literature.

\subsection{Instrumentation}

IR spectra were recorded in $\mathrm{KBr}$ pellets with a PerkinElmer Spectrum FT-IR spectrometer (RX-1) operating in the region 4000 to $400 \mathrm{~cm}^{-1}$. ${ }^{1} \mathrm{H}-\mathrm{NMR}$ was recorded at room temperature on an FT-NMR (Bruker Avance-II $400 \mathrm{MHz}$ ) spectrometer using DMSO- $d_{6}$ and $\mathrm{D}_{2} \mathrm{O}$ as solvents. Chemical shifts are mentioned in ppm downfield of internal standard tetramethylsilane (TMS). Elemental microanalyses (C, $\mathrm{H}$ and N) were conducted by using Perkin-Elmer (Model 240C) analyzer. Metal content was determined with the aid of AAS (Varian, SpectrAA 50B) by using standard metal solutions from Sigma-Aldrich, Germany. Mass spectra were recorded on a JMS-T100LC spectrometer. The purity of the prepared compounds was confirmed by thin layer chromatography (TLC) on silica gel plates and the plates were visualized with UV-light and iodine as and when required. The UV-Visible spectra were recorded in methanol with a JascoV-530 double beam Spectrophotometer at ambient temperature. Molar conductances were measured at $(298.15 \pm 0.01) \mathrm{K}$ with a Systronic conductivity meter, TDS-308. Magnetic susceptibilities were measured at room temperature using a magnetic susceptibility balance (Magway MSB Mk1, Sherwood Scientific Ltd). The melting point of the ligand and its complexes were determined by the open capillary method. Antibacterial activities (in vitro) of the synthesized compounds were tested by disc diffusion method. All the bacteria strains were procured from MTCC, Chandigarh, and were cultured at the Department of Microbiology, Raiganj University, Raiganj, West Bengal, India.

\subsection{Synthesis of 1-(2-aminoethyl)-3-ethylimidazolium tetrafluoroborate, [2-aeeim]B $F_{4}(1)$}

The amino functionalized ionic liquid [2-aeeim] $\mathrm{BF}_{4}$ was synthesized by following a literature procedure. ${ }^{29}$ Yield: $79 \%$; $\mathrm{C}_{7} \mathrm{H}_{14} \mathrm{~F}_{4} \mathrm{~N}_{3} \mathrm{~B}$ : Anal. Found: C, 37.02; H, 6.12; N, $18.38 \%$ Calc.: C, 37.04; H, 6.22; N, 18.51\%. IR $\left(\mathrm{KBr}, \mathrm{v} / \mathrm{cm}^{-1}\right)$ : $\left(v_{\mathrm{O}-\mathrm{H}}\right) 3447,3086,2896,1626,1452$, ( $\left.v_{\mathrm{BF} 4}\right) 1084$. ESI-MS $(\mathrm{m} / \mathrm{z})$ : Calc.: 140: Found: $140\left(\left[\mathrm{M}-\mathrm{BF}_{4}\right]^{+}, \mathrm{M}=\left[\mathrm{C}_{7} \mathrm{H}_{14} \mathrm{~N}_{3}\right]^{+}\right)$. ${ }^{1} \mathrm{H}$ NMR (400 MHz, $\mathrm{D}_{2} \mathrm{O}$, TMS): $\delta 3.63\left(2 \mathrm{H}, \mathrm{m}, \mathrm{NH}_{2}-\mathrm{CH}_{2}\right)$, $4.16\left(3 \mathrm{H}, \mathrm{s}, \mathrm{CH}_{3}\right), 4.49\left(1 \mathrm{H}, \mathrm{t}, \mathrm{N}-\mathrm{CH}_{2}\right), 4.56\left(1 \mathrm{H}, \mathrm{t}, \mathrm{N}-\mathrm{CH}_{2}\right)$, $7.40(1 \mathrm{H}, \mathrm{s}, \mathrm{NCH}), 7.50(1 \mathrm{H}, \mathrm{s}, \mathrm{NCH}), 8.61\left(2 \mathrm{H}, \mathrm{s}, \mathrm{NH}_{2}\right)$, $8.87(1 \mathrm{H}, \mathrm{s}, \mathrm{N}(\mathrm{H}) \mathrm{CN}) ;{ }^{13} \mathrm{C}$ NMR $\left(400 \mathrm{MHz}, \mathrm{D}_{2} \mathrm{O}, \mathrm{TMSO}\right)$ $\delta: 135.95,123,122.50,50.81,45.54,45.3,14.57$.

\subsection{Synthesis of imidazolium ionic liquid-tagged Schiff base, LH (2)}

The ionic liquid-tagged Schiff base (LH) was synthesized by a slight modification of a literature procedure. ${ }^{30} \mathrm{~A}$ mixture of 5-bromo-2-hydroxy benzaldehyde $(2.01 \mathrm{~g}, 10 \mathrm{mmol})$ and [2-aeeim] $\mathrm{BF}_{4}(2.27 \mathrm{~g}, 10 \mathrm{mmol})$ in methanol was stirred at room temperature for $12 \mathrm{~h}$. After completion of the reaction, as indicated by TLC, the reaction mixture was diluted with EtOH. The precipitate was filtered, washed with cold ethanol and dried to afford the expected ligand as a light yellow solid.

2.4a $L H(2): \quad$ M.p.: $98-100^{\circ} \mathrm{C}$; Yield: $65-70 \% ; \mathrm{C}_{14} \mathrm{H}_{17}$ $\mathrm{N}_{3} \mathrm{OBBrF}_{4}$ Anal. Found: $\mathrm{C}, 40.91 ; \mathrm{H}, 4.11 ; \mathrm{N}, 10.21 \%$. Calc.: C, 41.01; H, 4.18; N, 10.25(\%). IR (KBr, v/ $\left.\mathrm{cm}^{-1}\right)$ : $\left(v_{\mathrm{O}-\mathrm{H}}\right)$ 3449, $\left(v_{\mathrm{CH}=\mathrm{N}}\right)$ 1673, $\left(v_{\mathrm{C}-\mathrm{O}}\right)$ 1276, $\left(v_{\mathrm{BF} 4}\right)$ 1114. UV-Vis (Methanol) $\lambda \max / \mathrm{nm}: 218,250,336$. ESI-MS (m/z): Calc. 323: Found: $323\left(\left[\mathrm{M}-\mathrm{BF}_{4}\right]^{+}, \mathrm{M}=\left[\mathrm{C}_{14} \mathrm{H}_{17} \mathrm{~N}_{3} \mathrm{O}\right]^{+}\right) .{ }^{1} \mathrm{H}$ NMR: (400 MHz, DMSO-d $\left.\mathrm{d}_{6}, \mathrm{TMS}\right): \delta 3.32\left(3 \mathrm{H}, \mathrm{s}, \mathrm{CH}_{3}\right), 3.82(1 \mathrm{H}$, $\left.\mathrm{t}, \mathrm{N}-\mathrm{CH}_{2}\right), 3.99\left(1 \mathrm{H}, \mathrm{t}, \mathrm{N}-\mathrm{CH}_{2}\right), 4.52\left(1 \mathrm{H}, \mathrm{t}, \mathrm{N}-\mathrm{CH}_{2}\right), 6.91-$ $6.85(3 \mathrm{H}, \mathrm{m}, \mathrm{Ar}-\mathrm{H}), 7.33(1 \mathrm{H}, \mathrm{s}, \mathrm{NCH}), 7.42(1 \mathrm{H}, \mathrm{s}, \mathrm{NCH})$, $8.50(1 \mathrm{H}, \mathrm{s}, \mathrm{N}=\mathrm{CH}), 7.73(1 \mathrm{H}, \mathrm{s}, \mathrm{N}(\mathrm{H}) \mathrm{CN}), 9.10(1 \mathrm{H}, \mathrm{s}, \mathrm{OH})$. ${ }^{13} \mathrm{C}$ NMR (400 MHz, DMSO-d 6 , TMSO): $\delta 137.31,135.59$, 123.76, 123.09, 122.41, 122.25, 119.63, 53.91, 48.52, 48.14, $44.99,43.71,41.15,35.90$.

\subsection{Synthesis of metal complexes $(\mathbf{3}, \mathbf{4}$ and $\mathbf{5})$}

To a solution of ligand, $\mathrm{LH}(0.410 \mathrm{~g}, 1 \mathrm{mmol})$, in EtOH (20 $\mathrm{mL}$ ) solution of ethanolic metal acetate salt $\mathrm{Co}$ (II), $\mathrm{Ni}$ (II) and $\mathrm{Cu}(\mathrm{II}))$, viz., $(0.5 \mathrm{mmol})$ was added and the reaction mixture was refluxed for $4 \mathrm{~h}$ until the starting materials were completely consumed as monitored by TLC. On completion of the reaction, solvents were evaporated and the reaction 


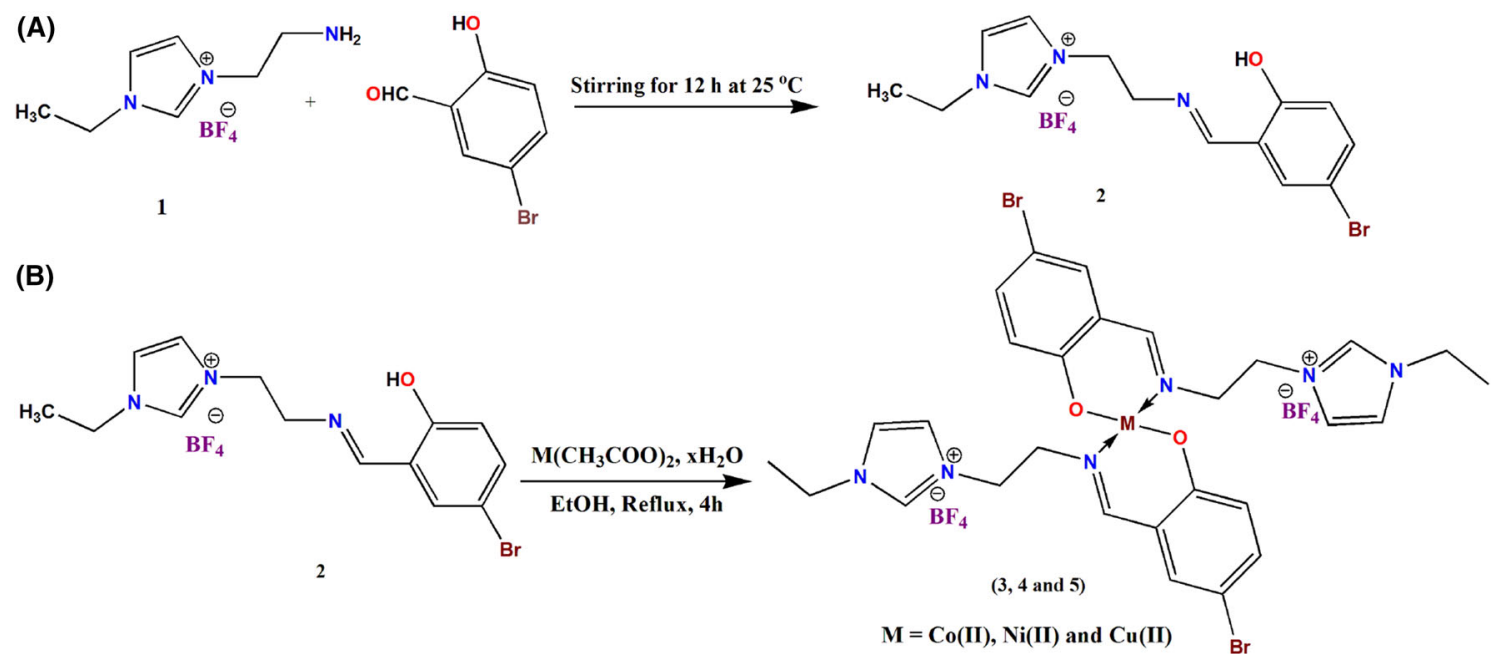

Scheme 1. Synthesis of the ionic liquid-tagged Schiff base, 1-\{2-[(2-hydroxy-5-bromobenzylidene)amino $]$ ethyl $\}-3-$ ethylimidazolium tetrafluoroborate (2), and M(II) complexes (3, 4 and 5) from LH (2).

mixture was cooled to room temperature. The precipitate was collected by filtration, washed successively with cold ethanol $(3 \times 10 \mathrm{~mL})$. Finally, it was dried in vacuum desiccators to obtain the solid product. The complexes are soluble in $N, N$-dimethylformamide, dimethylsulphoxide, acetonitrile, methanol and water. A schematic representation of the synthesis is shown in Scheme 1.

2.5a Co(II) complex (4): Brown solid; M.p.: 128 $130^{\circ} \mathrm{C} ; \mathrm{C}_{28} \mathrm{H}_{32} \mathrm{CoB}_{2} \mathrm{Br}_{2} \mathrm{~F}_{8} \mathrm{~N}_{6} \mathrm{O}_{2}$ : Anal. Found: $\mathrm{C}, 38.16 ; \mathrm{H}$, 3.53; N, 9.32, Co, 6.42\%. Calc.(\%) for C, 38.35; H, 3.68; $\mathrm{N}, 9.58 ; \mathrm{Co}, 6.72 \%$. IR $\left(\mathrm{KBr}, v / \mathrm{cm}^{-1}\right):\left(v_{\mathrm{O}-\mathrm{H} / \mathrm{H} 2 \mathrm{O}}\right) 3442$, $\left(v_{\mathrm{CH}=\mathrm{N}}\right) 1629,\left(v_{\mathrm{C}-\mathrm{O}}\right) 1316,\left(v_{\mathrm{BF} 4}\right) 1019,\left(v_{\mathrm{Br}}\right) 713,\left(v_{\mathrm{M}-\mathrm{O}}\right)$ 633, ( $\left.v_{\mathrm{M}-\mathrm{N}}\right)$ 523. UV-Vis (Methanol) $\lambda_{\max } / \mathrm{nm}: 220,338$, 394. ESI-MS (m/z): Calc. 701: Found: $701\left(\left[\mathrm{M}-\mathrm{BF}_{4}\right]^{+}, \mathrm{M}=\right.$ $\left[\mathrm{C}_{28} \mathrm{H}_{32} \mathrm{CoBr}_{2} \mathrm{~N}_{6} \mathrm{O}_{2}\right]^{+}$).

2.5b Ni(II) complex (5): Light green solid; M.p. 140$142{ }^{\circ} \mathrm{C} ; \mathrm{C}_{28} \mathrm{H}_{32} \mathrm{NiB}_{2} \mathrm{Br}_{2} \mathrm{~F}_{8} \mathrm{~N}_{6} \mathrm{O}_{2}$ : Anal. Found: $\mathrm{C}, 38.11 ; \mathrm{H}$, 3.50; N, 9.37, Ni, 6.33\%. Calc.: C, 38.36; H, 3.68; N, 9.58; $\mathrm{Ni}, 6.69 \%$. IR $\left(\mathrm{KBr}, v / \mathrm{cm}^{-1}\right):\left(v_{\mathrm{O}-\mathrm{H} / \mathrm{H} 2 \mathrm{O}}\right) 3437,\left(v_{\mathrm{CH}=\mathrm{N}}\right)$ 1627, ( $\left.v_{\mathrm{C}-\mathrm{O}}\right)$ 1314, $\left(v_{\mathrm{BF} 4}\right)$ 1018, $\left(v_{\mathrm{Br}}\right) 715$, ( $\left.v_{\mathrm{M}-\mathrm{O}}\right) 634$, $\left(v_{M-N}\right) 535$. UV-Vis (Methanol) $\lambda_{\max } / \mathrm{nm}: 219,340,400$. ESI-MS (m/z): Calc. 700: Found: $702\left([\mathrm{M}+2]-\mathrm{BF}_{4}, \mathrm{M}=\right.$ $\left[\mathrm{C}_{28} \mathrm{H}_{32} \mathrm{NiBr}_{2} \mathrm{~N}_{6} \mathrm{O}_{2}\right]^{+}$).

2.5c Cu(II) complex (6): $\quad$ Dark green solid; M.p. 147$149{ }^{\circ} \mathrm{C} ; \mathrm{C}_{28} \mathrm{H}_{32} \mathrm{CuB}_{2} \mathrm{Br}_{2} \mathrm{~F}_{8} \mathrm{~N}_{6} \mathrm{O}_{2}$ : Anal. Found: $\mathrm{C}$, 38.07; $\mathrm{H}, 3.49 ; \mathrm{N}, 9.31, \mathrm{Cu}, 6.99 \%$. Calc.: C, 38.15; H, 3.66; N,

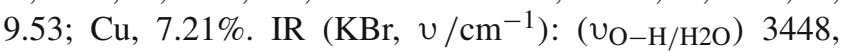
$\left(v_{\mathrm{CH}=\mathrm{N}}\right) 1625,\left(v_{\mathrm{C}-\mathrm{O}}\right) 1317,\left(v_{\mathrm{BF}}\right) 1014,\left(v_{\mathrm{Br}}\right) 717,\left(v_{\mathrm{M}-\mathrm{O}}\right)$ 648, $\left(v_{\mathrm{M}-\mathrm{N}}\right)$ 559. UV-Vis (Methanol) $\lambda_{\max } / \mathrm{nm}: 222,342$, 396. ESI-MS (m/z): Calc. 705: Found: $705\left(\left[\mathrm{M}-\mathrm{BF}_{4}\right]^{+}, \mathrm{M}=\right.$ $\left.\left[\mathrm{C}_{28} \mathrm{H}_{32} \mathrm{CuBr}_{2} \mathrm{~N}_{6} \mathrm{O}_{2}\right]^{+}\right)$.

\subsection{Antibacterial assay}

Antibacterial activities of the synthesized compounds were tested in vitro against the four Gram negative bacteria (E. coli, P. aeruginosa, $P$. vulgaris and E. aerogenes) and two Gram positive bacteria ( $S$. aureus and B. cereus) strains using agar disc diffusion method ${ }^{31,32}$ by NCCLS (National Committee for Clinical Laboratory Standards, 1997, India). The nutrient agar (Hi-Media Laboratories Limited, Mumbai, India) was autoclaved at $121^{\circ} \mathrm{C}$ and 1 atm for $15-20 \mathrm{~min}$. The sterile nutrient media was kept at $45-50{ }^{\circ} \mathrm{C}$, after that $100 \mu \mathrm{L}$ of bacterial suspension containing $10^{8}$ colony-forming units $(\mathrm{CFU}) / \mathrm{mL}$ were mixed with sterile liquid nutrient agar and poured into the sterile Petri dishes. Upon solidification of the media, filter disc (5 mm diameter) was individually soaked with different concentration $(10,20,30,40$ and $50 \mu \mathrm{g} / \mathrm{mL})$ of each extract and placed on the nutrient agar media plates. The different concentrations were made by adding with DMSO. The plates were incubated for $24 \mathrm{~h}$ at $37^{\circ} \mathrm{C}$. The diameter of the zone of inhibition (including disc diameter of $5 \mathrm{~mm}$ ) was measured. Each experiment was performed three times to minimize the error and the mean values were accepted.

\section{Results and Discussion}

All the isolated compounds were stable at room temperature to be characterized by different analytical and spectroscopic methods.

\subsection{IR spectral studies}

The assignments of the IR bands of the synthesized $\mathrm{Co}(\mathrm{II}), \mathrm{Ni}(\mathrm{II})$ and $\mathrm{Cu}(\mathrm{II})$ complexes have been made by comparing with the bands of ligand ( $\mathrm{LH}$ ) to determine the coordination sites involved in chelation. IR 

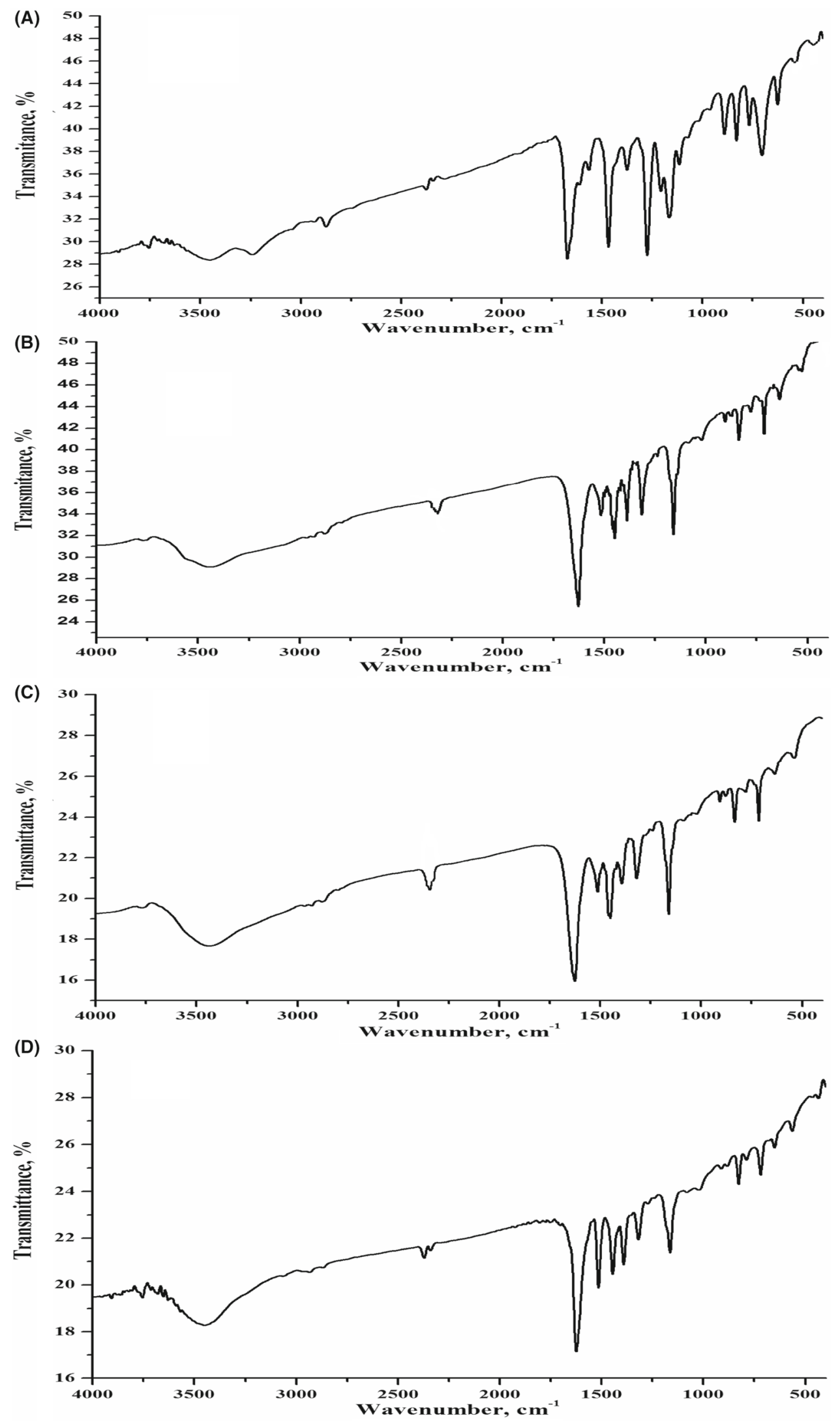

Figure 1. IR spectrum of: (A) 1-\{2-[(2-hydroxy-5-bromobenzylidene)amino]ethyl $\}$-3-ethylimidazolium tetrafluoroborate (2); (B) $\mathrm{Co}$ (II) complex (3); (C) $\mathrm{Ni}$ (II) complex and (4) and (D) $\mathrm{Cu}$ (II) complex (5). 
spectra of the ligand, LH (2) and its metal complexes (3 to 5) are given in Figure 1. Only the distinct and characteristic peaks have been discussed. IR spectra of the ligand exhibited a strong broad absorption band at $3450-3236 \mathrm{~cm}^{-1}$; this band was assigned to the hydrogen bonded $-\mathrm{OH}$ of the phenolic group with $\mathrm{H}-\mathrm{C}(=\mathrm{N})$ group of the ligand $(\mathrm{OH} \ldots \mathrm{N}=\mathrm{C}){ }^{33,34}$ All the complexes showed broad diffuse band at $3437-3448 \mathrm{~cm}^{-1}$ which may be attributed to the presence of the coordinated/solvated water or ethanol molecules. However, these bands appear stronger compare to that of the ligand due to the moisture content of the ligand subject to the intrinsic nature of the anion tetrafluoroborate. ${ }^{35-37}$ The band for phenolic C-O of free ligand was observed at $1276 \mathrm{~cm}^{-1}$. Upon complexation, this band was shifted to higher wave number $1314-1317 \mathrm{~cm}^{-1}$ for all the complexes. This fact suggests the involvements of phenolic $\mathrm{C}-\mathrm{O}$ in the coordination process. ${ }^{38}$ This interpretation is further confirmed by the appearance of $\mathrm{M}-\mathrm{O}$ band at $633-638 \mathrm{~cm}^{-1}$ in the spectra of the metal complexes. The intense band at $1673 \mathrm{~cm}^{-1}$ that corresponds to azomethine group $(-\mathrm{C}=\mathrm{N})$ in the free ligand is shifted to the lower frequencies in the range $1625-1629 \mathrm{~cm}^{-1}$ in case of the metal complexes, indicating the participation of azomethine group $(-\mathrm{C}=\mathrm{N})$ in the coordination sphere. ${ }^{39}$ This is further emphasized by the appearance of a new weak to medium intensity absorption band in the region $523-559 \mathrm{~cm}^{-1}$ that may be attributed to M$\mathrm{N}$ stretching vibration for the metal complexes. ${ }^{40}$ The bands in the range of $1014-1019 \mathrm{~cm}^{-1}$ for the spectra of metal complexes are assigned for B-F stretching frequency.

\subsection{Mass spectral studies}

To get information regarding the structure of the synthesized compounds at the molecular level, electrospray ionization (ESI) mass spectrometry was performed using methanol as solvent. ESI-MS spectrum of the compound, [2-aeeim] $\mathrm{BF}_{4}$ showed a peak at 140 $\left(\left[\mathrm{M}-\mathrm{BF}_{4}\right]^{+}\right.$, which corresponds to $\mathrm{M}^{+},\left[\mathrm{M}=\mathrm{C}_{7} \mathrm{H}_{14} \mathrm{~N}_{3}\right]^{+} .^{41}$ The ligand $(\mathrm{LH})$ exhibited a peak $(\mathrm{m} / z)$ at $323\left[\mathrm{M}-\mathrm{BF}_{4}\right]^{+}$, which can be assigned to $\left[\mathrm{M}=\mathrm{C}_{14} \mathrm{H}_{17} \mathrm{~N}_{3} \mathrm{O}\right]^{+} .{ }^{42}$ The $\mathrm{Co}(\mathrm{II})$ complex (3) displayed a peak $(\mathrm{m} / \mathrm{z})$ at 701.49 which corresponds to the $\left[\mathrm{M}-\mathrm{BF}_{4}\right]^{+}$ion. A peak $(m / z)$ at 701.62 in the ESI-MS spectrum of $\mathrm{Ni}(\mathrm{II})$ complex (4) is assigned to the $\left[\mathrm{M}+\mathrm{H}-\mathrm{BF}_{4}\right]^{+}$ion. In the ESI-MS spectrum, the $\mathrm{Cu}(\mathrm{II})$ complex $(\mathbf{5})$ exhibited a peak $(\mathrm{m} / \mathrm{z})$ at 705.74 which is assigned to the $\left[\mathrm{M}-\mathrm{BF}_{4}\right]^{+}$ion. ${ }^{43}$ (The ESI-MS spectra of the complexes and ligand are given in Figures S1 and S2 in Supplementary Information). The mass spectra of the ligand and complexes were in good agreement with the respective structures as revealed by the elemental and other spectral analyses.

\section{3 ${ }^{1} \mathrm{H}$ and ${ }^{13} \mathrm{C}$-NMR spectral studies}

${ }^{1} \mathrm{H}-\mathrm{NMR}$ and ${ }^{13} \mathrm{C}$-NMR spectra of ligand were recorded in DMSO- $d_{6}$ (Figures S3 and S4 in Supplementary Information). ${ }^{1} \mathrm{H}-\mathrm{NMR}$ of the ligand showed singlet at $8.50 \mathrm{ppm}$ is assignable to proton of the azomethine group $(-\mathrm{CH}=\mathrm{N}-)$ presumably due to the effect of the ortho-hydroxyl group in the aromatic ring. A singlet at 9.10 ppm can tentatively be attributed to hydroxyl proton. The Schiff base displayed downfield shift of the $-\mathrm{OH}$ proton is due to intermolecular $(\mathrm{O}-\mathrm{H}$...N) hydrogen bond. ${ }^{44}{ }^{13} \mathrm{C}-\mathrm{NMR}$ spectra of ligand exhibited peaks at $\delta 137.31$ and 135.59 presumably due to the phenolic (C-O) and imino $(-\mathrm{CH}=\mathrm{N})$ carbon atoms (due to ketoimine tautomerism). The chemical shifts of the aromatic carbons appeared at $\delta 123.76,123.09,122.41,122.25$ and 119.53. ( ${ }^{1} \mathrm{H}-\mathrm{NMR}$ and ${ }^{13} \mathrm{C}-\mathrm{NMR}$ spectra are given in Figures S3 and Figure S4, Supplementary Information).

\subsection{Molar conductance measurements}

The molar conductance of the complexes $\left(\Lambda_{m}\right)$ were measured by using the relation $\Lambda_{m}=1000 \times \kappa / c$, where $c$ and $\kappa$ stands for the molar concentration of the metal complexes and specific conductance, respectively. The complexes $\left(1 \times 10^{-3} \mathrm{M}\right)$ were dissolved in $N, N$ dimethylformamide and their molar conductivities were measured at $(298.15 \pm 0.01) \mathrm{K}$. The conductance values were in the range of 134,131 and $130 \mathrm{~S} \mathrm{~cm}^{-1} \mathrm{~mol}^{-1}$, respectively, for the metal complexes ( 3 to $\mathbf{5}$ ), indicating their 1:2 (M:L) electrolytic behaviour.

\subsection{Electronic absorption spectral and magnetic moment studies}

UV-Visible spectra of the ligand and the metal complexes (Figure 2) were recorded at ambient temperature using methanol as solvent. The electronic spectrum of free Schiff base exhibited three absorption bands at 336, 250 and $218 \mathrm{~nm}$ due to $\mathrm{n} \rightarrow \pi^{*}, \pi \rightarrow \pi^{*}$ and transitions involved with the imidazolium moiety, respectively. ${ }^{45,46}$ For the complexes, the bands that appeared below 350 $\mathrm{nm}$ were ligand centred transitions $\left(\mathrm{n} \rightarrow \pi^{*}\right.$ and $\pi \rightarrow \pi^{*}$ ). The Co(II) complex (3) displayed a band at $394 \mathrm{~nm}$ which could be assigned to the combination of ${ }^{2} \mathrm{~B}_{1 \mathrm{~g}} \rightarrow{ }^{1} \mathrm{~A}_{1 \mathrm{~g}}$ and ${ }^{1} \mathrm{~B}_{1 \mathrm{~g}} \rightarrow{ }^{2} \mathrm{E}_{\mathrm{g}}$ transitions and supporting square planar geometry. ${ }^{47,48}$ The complex (3) shows the magnetic moment of $2.30 \mathrm{BM}$ due to one unpaired electron. The Ni(II) complex (4) was diamagnetic and the 


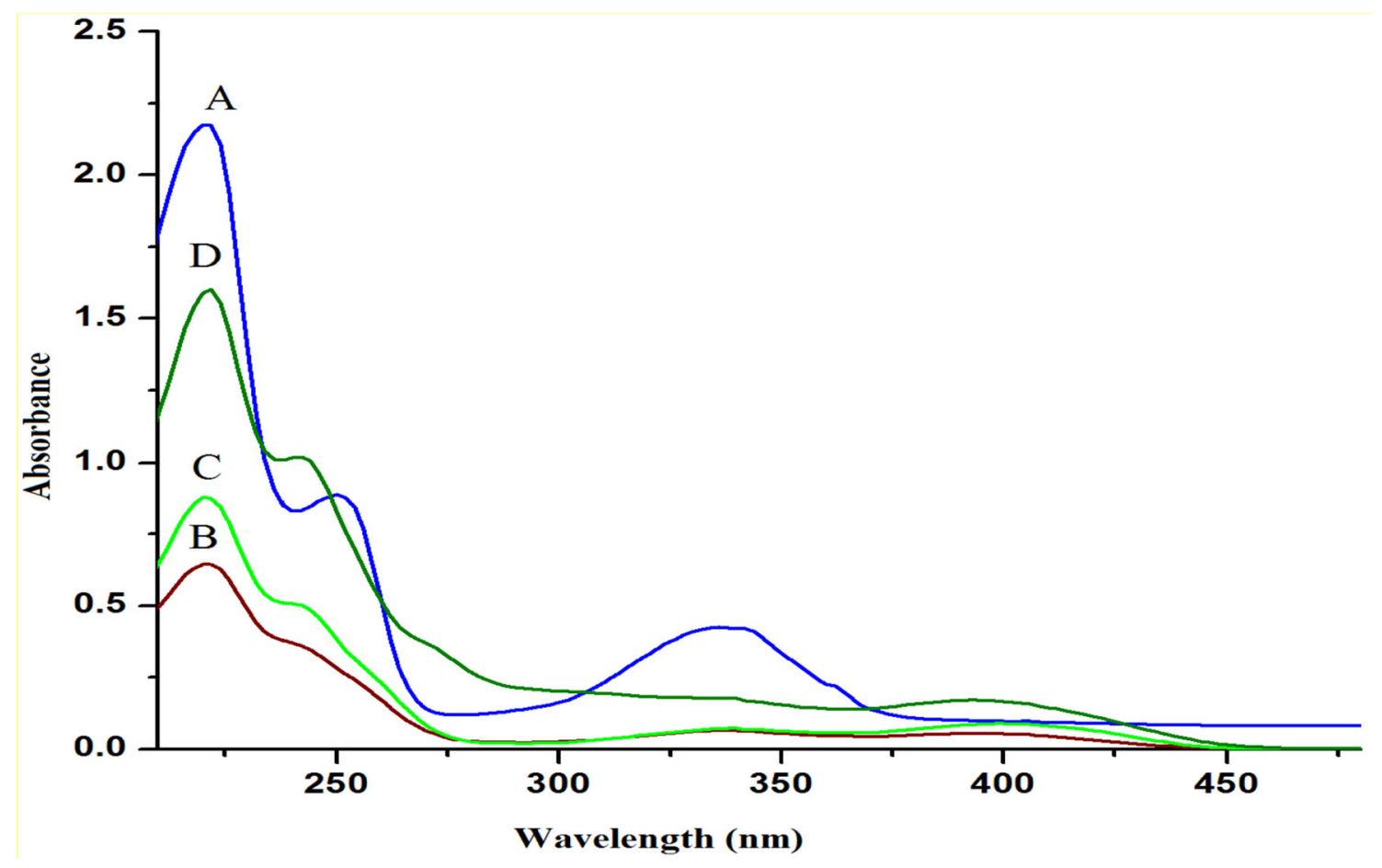

Figure 2. UV-visible spectra in methanol (concentration of the solutions $\left.1 \times 10^{-4} \mathrm{M}\right)$ : (A) the ligand(2); (B) $\mathrm{Co}(\mathrm{II})$ complex(3); (C) Ni(II)complex(4) and (D) Cu(II) complex(5).


Figure 3. Inhibition zones for the ligand (2), $\mathrm{Co}(\mathrm{II})$ complex (3), $\mathrm{Ni}(\mathrm{II})$ complex (4) and $\mathrm{Cu}(\mathrm{II}) \mathrm{complex}(\mathbf{5})$. 
band around $400 \mathrm{~nm}$ due to ${ }^{1} \mathrm{~A}_{1 \mathrm{~g}} \rightarrow{ }^{1} \mathrm{~B}_{1 \mathrm{~g}}$ transition is consistent with low spin square planar geometry. ${ }^{49}$ The UV-visible spectra of $\mathrm{Cu}$ (II) complex (5) showing $\mathrm{d} \rightarrow$ $\pi^{*}$ metal-ligand charge transfer transition (MLCT) in the region $396 \mathrm{~nm}$ had been assigned to the combination of ${ }^{2} \mathrm{~B}_{1 \mathrm{~g}} \rightarrow{ }^{2} \mathrm{E}_{\mathrm{g}}$ and ${ }^{2} \mathrm{~B}_{1 \mathrm{~g}} \rightarrow{ }^{2} \mathrm{~B}_{2 \mathrm{~g}}$ transitions in a distorted square-planar environment. ${ }^{50,51}$ The observed magnetic moment for $\mathrm{Cu}$ (II) complex (5) was 1.82 B.M. consistent with the presence of a single unpaired electron. ${ }^{52}$

\subsection{Antibacterial activities}

Minimum inhibitory concentration was measured by Broth Micron dilution susceptibility method. Serial dilutions of sample solutions were made in nutrient broth medium. Then $1 \mathrm{~mL}$ of standard ( $0.5 \mathrm{McF}$ arland) bacteria suspension was inoculated into each of these tubes. A similar nutrient broth tube without sample was also inoculated and used as a control. The tubes were kept at $37^{\circ} \mathrm{C}$ for $24 \mathrm{~h}$. The lowest concentration of sample which inhibited bacterial growth was considered as minimum inhibitory concentration. Final confirmation was done by streaking on nutrient agar medium. The samples under study have shown promising result against all the bacterial strains (Table S1 in Supplementary Information). From the inhibitory values, it is clear that the Schiff based ligand is most effective against five organisms (MIC $10 \mu \mathrm{g} / \mathrm{mL}$ ) except E. aerogenes. Co(II) complex (3) is most effective against $P$. vulgaris and E. aerogens. $\mathrm{Ni}(\mathrm{II})$ complex (4) is observed very active against E. coli, S. aereus, P. aeruginosa and E. aerogenes (MIC $10 \mu \mathrm{g} / \mathrm{mL}$ ). It is seen that $\mathrm{Cu}$ (II) complex (5) is most effective among the others samples due to their MIC value of $20 \mu \mathrm{g} / \mathrm{mL}$ against $E$. coli, $S$. aereus, B. cereus and $30 \mu \mathrm{g} / \mathrm{mL}$ against $P$. aeruginosa and $P$. vulgaris. The results are shown in Figure 3.

\section{Conclusions}

In this research, the preparation and physico-chemical characterization of new $\mathrm{Co}$ (II), $\mathrm{Ni}$ (II) and $\mathrm{Cu}$ (II) complexes bearing an ionic liquid-supported Schiff base 1\{2-[(2-hydroxy-5-bromobenzylidene)amino]ethyl\}-3ethylimidazolium tetrafluoroborate as ligand, have been reported. The Schiff base and metal complexes were characterized by spectral and analytical methods. The spectral and magnetic susceptibility measurements suggested that the bidentate ligand coordinates to the central metal ion through the azomethine nitrogen and phenolic oxygen atoms, yielding square planar complexes. The synthesized complexes showed reasonable antibacterial activity against the tested bacteria. $\mathrm{Cu}$ (II) complex (5) showed most effective activity effective activity than the other samples.

\section{Supplementary Information (SI)}

Experimental biological assays data, ESI-MS and NMR spectral data for the ligand and complexes are given as Supplementary Information, available at www.ias.ac.in/chemsci.

\section{Acknowledgements}

The authors are grateful to the SAIF, NEHU, Guwahati, India for ${ }^{1} \mathrm{H}$ NMR, ${ }^{13} \mathrm{C}$ NMR, ESI-MS and elemental analysis.

\section{References}

1. Earle M J, Esperanc J M S S, Gilea M A, Lopes J N C, Rebelo L P N, Magee J, Seddon K R and Widegren J A 2006 The distillation and volatility of ionic liquids Nature 439831

2. Sakaebe $\mathrm{H}$ and Matsumoto $\mathrm{H} 2003 \mathrm{~N}$-Methyl- $N$ propylpiperidinium bis(trifluoromethane sulfonyl)imide (PP13-TFSI) - novel electrolyte base for Li battery Electrochem. Commun. 5594

3. Rogers R D and Seddon K R 2003 Ionic LiquidsSolvents of the Future? Science $\mathbf{3 0 2} 792$

4. Sheldon R 2005 Green solvents for sustainable organic synthesis: state of the art Green Chem. 7267

5. Wasserscheid P and Keim W 2000 Ionic Liquids-New "Solutions" for Transition Metal Catalysis Angew. Chem. Int. Ed. 393773

6. Anastas P T and Warner J C 1998 In Green ChemistryTheory and Practice (New York: Oxford University Press Inc.)

7. Visser A E, Swatloski R P, Reichert W M, Mayton R, Sheff S, Wierzbicki A, Davis Jr. J H and Rogers R D 2001 Task-specific ionic liquids for the extraction of metal ions from aqueous solutions Chem. Chem. Commun. 1135 136

8. (a) Zhou Y and Antonietti M 2003 Preparation of Highly Ordered Monolithic Super-Microporous Lamellar Silica with a Room-Temperature Ionic Liquid as Template via the Nanocasting Technique Adv. Mater. 15 1452; (b) Taubert A and Li Z 2007 Inorganic materials from ionic liquids Dalton Trans. 7723

9. (a) Endres F, Bukowski M, Hempelmann R and Natter H 2003 Electrodeposition of nanocrystalline metals and alloys from ionic liquids Angew. Chem. 115 3550; (b) Abbott A P, Capper G, Swain B G and Wheeler D A 2005 Electropolishing of stainless steel in an ionic liquid Trans. Inst. Met. Finish. 8351

10. Miao W and Chan T H 2006 Ionic-liquid-supported synthesis: a novel liquid-phase strategy for organic synthesis Acc. Chem. Res. 39897

11. Kamal A and Chouhan G 2005 A task-specific ionic liquid [bmim] scn for the conversion of alkyl halides to alkyl thiocyanates at room temperature Tetrahedron Lett. 46 1489

12. Lee S 2006 Functionalized imidazolium salts for taskspecific ionic liquids and their applications Chem. Commun. 1049 
13. Luo S, Mi X, Zhang L, Liu S, Xu H and Cheng J P 2007 Functionalized ionic liquids catalyzed direct aldol reactions Tetrahedron 631923

14. Bates E D, Mayton R D, Ntai I and Davis J H $2002 \mathrm{CO}_{2}$ Capture by a Task-Specific Ionic Liquid J. Am. Chem. Soc. 124926

15. D'Anna F, Marullo S and Noto R 2008 Ionic liquids/[bmim] [n3] mixtures: Promising media for the synthesis of aryl azides by snar. J. Org. Chem. 736224

16. Davis Jr J H 2004 Task-specific ionic liquids Chem. Lett. 331072

17. Tang S, Babai A and Mudring A V 2008 Europiumbasierte ionische Flüssigkeiten als lumineszierende weiche Materialien Angew. Chem. 1207743

18. Patel S A, Sinha S, Mishra A N, Kamath B V and Ramb R N 2003 Olefin epoxidation catalysed by Mn(II) Schiff base complex in heterogenised-homogeneous systems J. Mol. Catal. A 19253

19. Peng Y, Cai Y, Song G and Chen J 2005 Ionic LiquidGrafted Mn(III)-Schiff Base Complex: A Highly Efficient and Recyclable Catalyst for the Epoxidation of Chalcones Synlett 1421470

20. Hadjikakou S K and Hadjiliadis N 2009 Antiproliferative and anti-tumor activity of organotin compounds Coord. Chem. Rev. 253235

21. Garoufis A, Hadjikakou S K and Hadjiliadis N 2009 Palladium coordination compounds as anti-viral, antifungal, anti-microbial and anti-tumor agents Coord. Chem. Rev. 2531384

22. Patil S A, Naik V H, Kulkarni A D and Badami P S 2010 DNA cleavage, antimicrobial, spectroscopic and fluorescence studies of $\mathrm{Co}$ (II), $\mathrm{Ni}$ (II) and $\mathrm{Cu}$ (II) complexes with SNO donor coumarin Schiff bases Spectrochim. Acta A 75347

23. Dinda R. Saswati R, Schmiesing C S, Sinn E, Patil Y P, Nethaji M, Stoeckli-Evans H and Acharyya R 2013 Novel metal-free, metallophthalocyanines and their quaternized derivatives: Synthesis, spectroscopic characterization and catalytic activity of cobalt phthalocyanine in 4-nitrophenol oxidation Polyhedron 50 354

24. Yamada M, Araki K and Shiraishi S 1990 Oxygenation of 2,6-di-t-butylphenol catalysed by a new cobalt(II) complex [Co(babp)]: a salen analogue having higher catalytic activity, selectivity, and durability J. Chem Soc. Perkin Trans. 12687

25. Sheldon R A, Arends I W C E and Lempers H E B 1998 Liquid phase oxidation at metal ions and complexes in constrained environments Catal. Today $\mathbf{4 1} 387$

26. Grasselli R K 1999 Advances and future trends in selective oxidation and ammoxidation catalysis Catal. Today 49141

27. Saha S, Brahman D and Sinha B 2015 Cu(II) complexes of an ionic liquid-based Schiff base [1-2-((2-hydroxybenzylidene) amino)ethyl-3methylimidazolium]PF6: Synthesis, characterization and biological activities J. Serb. Chem. Soc. 8035

28. Saha S, Das A, Acharjee K and Sinha B 2016 Synthesis, characterization and antibacterial studies of $\mathrm{Mn}(\mathrm{II})$ and $\mathrm{Co}$ (II) complexes of an ionic liquid tagged Schiff base $J$. Serb. Chem. Soc. 801151
29. Song G, Cai Y and Peng Y 2005 Amino-functionalized ionic liquid as a nucleophilic scavenger in solution phase combinatorial synthesis J. Comb. Chem. 7561

30. Li B, Li Y Q and Zheng J 2010 A novel ionic liquidsupported Schiff base ligand applied in the Pd-catalyzed Suzuki-Miyaura coupling reaction Arkivoc IX 163

31. Clinical and Laboratory Standards Institute (NCCLS) 2006 Performance Standards for Antimicrobial Disk Susceptibility Tests: Approved Standard, $9^{\text {th }}$ ed. M2-A9, Wayne, PA

32. Clinical and Laboratory Standards Institute (NCCLS) 2006, Methods for Dilution Antimicrobial Susceptibility Tests for Bacteria that Grow Aerobically: Approved Standard, 7th ed. M7-A7, Wayne, PA

33. Yıldız M, Kılıc Z and Hökelek T 1998 Intramolecular hydrogen bonding and tautomerism in Schiff bases. Part I. Structure of 1,8-di[N-2-oxyphenyl-salicylidene]-3,6dioxaoctane J. Mol. Struct. 4411

34. Yeap G - Y, Ha S -T, Ishizawa N, Suda K, Boey P -L and Mahmood W A K 2003 Synthesis, crystal structure and spectroscopic study of parasubstituted 2-hydroxy3-methoxybenzalideneanilines J. Mol. Struct. 65887

35. Abdel-Latif S A, Hassib H B and Issa Y M 2007 Studies on some salicylaldehyde Schiff base derivatives and their complexes with $\mathrm{Cr}(\mathrm{III}), \mathrm{Mn}(\mathrm{II}), \mathrm{Fe}(\mathrm{III}), \mathrm{Ni}(\mathrm{II})$ and $\mathrm{Cu}(\mathrm{II})$ Spectrochim. Acta A 67950

36. Wang J, Pei Y, Zhao Y and Hu Z 2005 Recovery of amino acids by imidazolium based ionic liquids from aqueous media Green Chem. 196

37. Han D and Row K H 2010 Recent application of ionic liquids in separation technology Molecules 152405

38. Mahmoud M A, Zaitone S A, Ammar A M and Sallam S A 2016 Synthesis, structure and antidiabetic activity of chromium(III) complexes of metformin Schiff-bases $J$. Mol. Struct. 110860

39. Kohawole G A and Patel K S 1981 The stereochemistry of oxovanadium(IV) complexes derived from salicylaldehyde and polymethylenediamines J. Chem. Soc., Dalton Trans. 61241

40. Adams D M 1967 In Metal-Ligand and Related Vibrations: A Critical Survey of the Infrared and Raman Spectra of Metallic and Organometallic Compounds (London: Edward Arnold)

41. Cai Y, Peng Y and Song G 2006 Amino-functionalized ionic liquid as an efficient and recyclable catalyst for Knoevenagel reactions in water Catal. Lett. 1096

42. Muthayala M K and Kumar A 2012 Ionic LiquidSupported Aldehyde: A Highly Efficient Scavenger for Primary Amines ACS Comb. Sci. 145

43. Nehra P, Khungar B, Pericherla K, Sivasubramanian S C and Kumar A 2014 Imidazolium ionic liquid-tagged Palladium complex: An efficient catalyst for Heck and Suzuki reactions in aqueous medium Green Chem. 14 4266

44. Li B, Li Y Q, Zheng W J and Zhou M Y 2009 Synthesis of ionic liquid supported Schiff bases Arkivoc 11165

45. Silverstein R M 2005 In Spectrometric Identification of Organic Compounds $7^{\text {th }}$ edn. (Location: John Wiley)

46. Peral F and Gallego E 1997 Self-association of imidazole and its methyl derivatives in aqueous solution. A study by ultraviolet spectroscopy J. Mol. Struct. 415187 
47. Shakir M, Nasam O S M, Mohamed A K and Varkey S P 1996 Transition metal complexes of 13-14membered tetraazamacrocycles: Synthesis and characterization Polyhedron 151283

48. Chem L S and Cummings S C 1978 Synthesis and characterization of cobalt(II) and some nickel(II) complexes with $\mathrm{N}, \mathrm{N}$ '-ethylenebis(p-X-benzoylacetone iminato) and N,N'-ethylenebis(p-X-benzoylmonothioacetone iminato) ligands Inorg. Chem. 172358

49. Del Paggio A A and McMillin D R 1983 Substituent effects and the photoluminescence of $\mathrm{Cu}(\mathrm{PPh} 3) 2(\mathrm{NN})+$ systems Inorg. Chem. 22691
50. Natarajan C, Tharmaraj P and Murugesan R 1992 In Situ Synthesis and Spectroscopic Studies of Copper(II) and Nickel(II) Complexes of 1-Hydroxy-2Naphthylstyrylketoneimines J. Coord. Chem. 26 205

51. Dehghanpour S, Bouslimani N, Welter R and Mojahed F 2007 Synthesis, spectral characterization, properties and structures of copper(I) complexes containing novel bidentate iminopyridine ligands Polyhedron 26 154

52. Lever A B P 1984 In Inorganic Electronic Spectroscopy $2^{\text {nd }}$ edn. (Amsterdam: Elsevier) 